\title{
Does Mass Culture Mean a Crisis of Values? Dwight Macdonald's Position and the Issue of Its Topicality
}

\author{
Tomasz Stefaniuk \\ https://orcid.org/0000-0002-0009-3142
}

Dwight Macdonald was generally right in describing the beginnings of mass culture, or Masscult, and its essential features. Besides, he rightly predicted that Masscult - focusing on profit, not on the quality of the cultural goods offered - would gain a dominant position in relation to higher culture. However, he could not predict what was to come, especially the revolution in the field of information transfer and emergence of new ways of cultural goods distribution. According to him, Masscult means a crisis of values. This is because financial profits by no means balance the fall of art and culture, traditionally understood. Masscult is a threat especially to such values as the value of a work of art, the value of a "natural" human life and the value of a "natural" social relations.

Keywords: Dwight Macdonald, culture, theory of culture, mass culture, Masscult, criticism of mass culture

Today, everyone realizes that we are functioning within the framework of mass culture, or, as Dwight Macdonald would say, Masscult - because according to him, what we call mass culture does not deserve to be described as culture at all.

TOMASZ STEFANIUK, habilitated doctor, Institute of Philosophy, Maria Curie-Skłodowska University in Lublin, Poland; address for correspondence: Instytut Filozofii UMCS, Pl. Marii CurieSkłodowskiej 4, PL 20-031 Lublin. E-mail: tomasz.stefaniuk@poczta.lublin.umcs.pl 
If so, does the dominant position of mass culture influence values, does it change the way they function? Should we now talk about a crisis of values, or even about the "end of values", or rather, on the contrary, should it be stated that mass culture enables functioning of certain values? If the latter was to be correct, what values are "allowed" to function within mass culture?

It seems that we cannot speak about the end of values, at least not literally; this is because, according to the definition given by Heinrich Rickert, a NeoKantian German philosopher, values are something that does not exist, but something that is valid ${ }^{2}$. How could something that never existed cease to exist? Values can only stop functioning, or cease to be valid, as well as they may cease to be selected; certain values can be chosen in place of others etc., but they are not beings in the classical, philosophical understanding of the term "being". In other words, there are beings that constitute the world around us, as well as the "world" (or perhaps the sphere or area) of objectively existing, absolutely valid values, which are chosen by people because they are important to them. It is thanks to them that the human world - and more precisely, culture - is what it is, i.e. a field into which, unlike in nature, certain meanings are introduced. According to Rickert, the world of nature is devoid of any sense; people, as well as human communities, create, develop and preserve certain cultures that are "vehicles" for a certain set of values ${ }^{3}$.

We can only guess if such a Rickertian understanding of the relationship between culture and values would suit Macdonald. It is unlikely that he knew Rickert's idea well, because he was a writer and critic of culture rather than an educated philosopher, although the problem of the existence and functioning of values was of some interest to him. For example, in one of his essays, Macdonald distinguishes, in addition to "the world of science", "the world of values" - where judgements are ultimately subjective, but "men do have something in common in those fields" ${ }^{4}$. Nevertheless, his reflection was not a philosophical reflection, but simply a reflection on culture and its functioning.

${ }^{2}$ Cf., for instance, J. L. Martin, Simmel and Rickert on Aesthetics and Historical Explanation, [in:] Theories of Action and Morality: Perspectives from Philosophy and Social Theory, M. Alznauer, J. M. Torralb (eds.), Georg Olms Verlag, Hildesheim 2016, pp. 126-135.

${ }^{3}$ Ibid.

${ }^{4}$ Cf. D. Macdonald, The Responsibility of Peoples and Other Essays in Political Criticism, Greenwood Press, Westport 1976, pp. 233-234. 
That does not mean, however, that it was worthless, also for philosophy. It can be studied from the perspective of a philosophical reflection on culture, because Macdonald posed some important philosophical questions about culture, especially perhaps about the relationship between values and the development of culture; although he did not do this, which should be emphasized, explicitly. The term "values" was used in his writings very rarely; perhaps he did not realize that it is one of the key terms that allow us to understand the culture in depth, at least if we accept Rickert's perspective, which many cultural researchers do more or less consciously.

Although Macdonald rarely uses the term "values", he writes, indirectly, about certain values that are, in his opinion, fundamental to the culture and life of people (both individual and collective). These values are: (a) art, or perhaps the value of the artist's individual approach to the world, which is achieved through the creation of a new work of $\operatorname{art}^{5}$; (b) humane life, or such a life which is in a sense "natural", and does not lead to alienation, rejection or negation of the "natural man"; (c) community life, i.e. people forming a collective, for example they have a common memory, common goals, common aspirations, some common interest etc.

If it were not for his conviction that in the Masscult era there is a huge crisis of values, Macdonald would probably not speak at all. The dominance of mass culture means, in his mind, a crisis of values, at least such as those mentioned above. Indeed, it can be assumed that, for example, flooding the market with a mass cultural product means economic growth, earnings of producers etc.; however, according to Macdonald, this cannot be treated as a value in relation to artistic creation and culture. For the purpose of artistic creation is a work of art, for instance a valuable film, not a film that simply sells well. As is easy to notice, Macdonald does not take a pluralistic position. According to him, there is no alternative, i.e. either through cultural activity genuine values appear (here it will be a work presenting an individual, thought-out, even subjective vision of the

\footnotetext{
${ }^{5}$ As he writes, "Masscult [...] is not just unsuccessful art. It is non-art. It is even anti-art"; cf. Macdonald, Masscult and Midcult: Essays Against the American Grain, New York Review of Books, New York 2011, p. 4.
} 
world), or there is no culture and no values at all $^{6}$. The very existence of culture is therefore possible only when the originators of culture refer to certain, specific, and not to any values.

Analogical remarks can be applied to the other two areas in which values exist (outside the area of art and artistic creation), namely to individual human life and collective life. According to Macdonald, in such a reality in which the functioning of culture is a copy of a large factory or enterprise - perfectly organized for the purposes of increasing production and aimed only at profit ${ }^{7}-$ values that have so far allowed or conditioned the existence of culture as such are at risk. In other words, it means that man cannot be himself, culture cannot be itself (and even cannot be at all), and community life cannot be itself if everything in culture is limited to the "production" of cultural goods and to increasing financial profit; it is therefore more dangerous than it might seem at first. Because of the dominant position of mass culture, man himself is in endangered; without culture, and without values realized and maintained in it, we cease, in a sense, to be people, and we become only necessary cogs in the machinery of production and consumption of cultural goods (which without us, i.e. without buyers, or without customers, cannot function). Macdonald tries, therefore, to convince us that being a cog of a certain machinery and being a man, i.e. someone participating in culture, is not the same.

Analyzing Macdonald's reflections on how mass culture functions, it is impossible to escape from certain questions or doubts. First of all, whether presenting such a picture of mass culture - that is, stressing the fatal influence of mass culture on how values exist - the American author is not exaggerating; in other words, is his position not too radical, too uncompromising? Is there really no other option and does it have to be either mass culture or real culture (High Culture, in his own words)? Perhaps since the first publication of his reflections on these issues, i.e. in the last sixty-five years, the world has changed so much that such a view has at least partly become outdated?

\footnotetext{
${ }^{6}$ Other theoreticians and critics of culture also mention the disappearance of individuality in mass culture; cf., for instance, T. W. Adorno, The Culture Industry: Selected Essays on Mass Culture, Routledge, London 2005, p. 69 et. pass.

${ }^{7}$ According to Macdonald, "The production line grinds out a uniform product [...] whose humble aim is [...] distraction. It [...] must be easy to assimilate”; cf. Macdonald, Masscult and Midcult, op. cit., p. 5.
} 
"Permanent crisis" or mass culture in the historical perspective

What seems to be the undoubted value of Macdonald's reflection on culture is his study of the origins of mass culture in a historical perspective ${ }^{8}$. The central point here are the very beginnings of the situation that, in his opinion, ultimately lead not only to the crisis of culture (mass culture does not even have the theoretical possibility of being good, as he writes ${ }^{9}$ ), but also to the crisis of values, and that means rising, development and then taking over the dominant role by mass culture.

The origins of mass culture are, according to Macdonald, related to the negation of the role of the elites that so far dealt with art and culture, but also the progressive industrialization should be mentioned here ${ }^{10}$. Previously, in the West, there was a division into two areas of culture: high culture and folk culture; and it seemed to be a sort of natural state ${ }^{11}$; then, however, some revolutionary changes took place leading to the creation and consolidation of the dominant role of Masscult. The basic reasons for the emergence and development of mass culture are, according to Macdonald, democratization and progress in the field of education ${ }^{12}$. In his view, Macdonald emphasized, referring to the history of culture, division into the elite (aristocracy in the basic meaning of the word, together with their high culture) and people (being a "vehicle" for folk culture) ${ }^{13}$.

Despite this former division, there was something that connected the world of the elite with the world of simple, uneducated people who did not have access to palace salons, opera halls etc:; namely, they had their own culture; because, in Macdonald's opinion, folk culture was a culture, in contrast to Masscult. With the advent of mass culture, the wall separating the "people's kitchen garden" from

\footnotetext{
${ }^{8}$ For instance, Macdonald begins his essay by saying: "For about two centuries Western culture has in fact been two cultures [...]"; cf. ibidem, p. 3. The historic beginnings of Masscult are eighteencentury England and its literature, and the development of commercial press, but these considerations do not need to be referred more specifically in this article; cf. Macdonald, ibidem, p. 14

${ }^{9}$ Cf. ibidem, p. 4.

${ }^{10}$ About the beginnings of Masscult: "The industrial revolution produced the masses"; cf. ibidem, p. 12. There were always masses, but these masses only in the late eighteenth century in Europe began to play a certain role, social and cultural; cf. ibidem, pp. 12-13.

${ }^{11}$ Cf. ibidem, p. 13.

${ }^{12}$ According to Macdonald, "Masscult is very, very democratic"; cf. ibidem, p. 11.

${ }^{13}$ Mascult has grown from folk culture; cf. ibidem, p. 13. The difference it that Masscult is "fabricated by technicians hired by businessmen"; cf. ibidem.
} 
"the great formal park" of their masters was demolished ${ }^{14}$. It would seem that it would be beneficial for the functioning of the broadly understood culture, but according to Macdonald it was just the opposite - it was the beginning of the end of culture as such ${ }^{15}$. Thus, the situation in which the monopoly of the upper class was broken, and in which at the same time the democratization of social life and general education led to the emergence of significant cultural needs of the "awakened masses" did not become the source of a new culture. On the contrary, this situation has led to the birth of "anti-culture", because Masscult can justifiably be named so; and Macdonald gives many examples taken from the culture of his own time, analyzing, among others, the development of film making or literature (understood as an area of artistic activity), which in his opinion testify to the legitimacy of this thesis ${ }^{16}$. Undoubtedly, the main reason for the fall of culture in the Masscult era is bringing it to the possibility of earning a profit. Along with the emergence of the aroused cultural needs of the masses, businessmen appeared; and their goal was only earning. Thus, businessmen invented and proposed a new type of product (yes, in Masscult, instead of cultural goods, we have a product ${ }^{17}$ ). This product has the following characteristics: It is not something that belongs to culture in the precise sense of the word, because culture is something valuable; in other words, it is kitsch, not art (the term "kitsch" is Macdonald's synonym for the Masscult product). It is finally something intended for mass consumption and this is crucial, because mass consumption means generating the greatest profit from the sale of products, which is logical considering that the goal here is

\footnotetext{
${ }^{14}$ For folk culture as people's kitchen-garden and High Culture as great formal park of their masters cf. ibidem.

${ }^{15}$ In addition, the American author mentions other significant reasons for the "victory of Masscult over culture"; firstly, the mass culture product has been adapting to the level of the buyer from the very beginning; secondly, the "originators" of Masscult's products must have many of "mass man" in themselves, i.e. they must feel and understand him well; cf. Macdonald, Masscult \& Midcult, op. cit., pp. 26-31.

${ }^{16}$ For Macdonald as a film critic cf., for instance, Thomas Schatz, Hollywood: Cultural Dimensions: Ideology, Identity and Cultural Industry Studies, Taylor \& Francis, London 2004, pp. 139140.

${ }^{17}$ Macdonald clearly writes about the fact that Masscult is produced. For example, when comparing two writers, Erle Stanley Gardner and Edgar Allan Poe, Macdonald notes that the books the former "seem to have been produced rather than composed", and further notes that "he is marketing a standard product, as Kleenex"; cf. Macdonald, op. cit., p. 6. The difference between Mr. Poe and Mr. Gardner for Macdonald seems to be the difference between high culture and Masscult; cf. ibidem, p. 7.
} 
not to create works of art, but to earn money. The criterion is therefore based on the conviction that in the field of culture something is not valuable because it is valuable in itself (as a cultural good), but that more valuable sells better. Accepting such a criterion, according to Macdonald, means of course the end of culture.

It is difficult not to agree with that fragment of Macdonald's reflection on culture and its fall in the Masscult era, although perhaps the views of the American author are sometimes too extreme and too uncompromising. More specifically, it is difficult to disagree with the fact that the functioning of mass culture leads in effect to lowering the level of culture as such. In the Masscult era it will not be appreciated that on the "cultural market" good literature or good movies might be found, but that there are things that are willingly bought by people. And because the taste of most people is perhaps bad, valuable literature or movies are now in decline. If most buyers are looking for books that are simple to receive, they will get them; the same applies to movies, music and other cultural fields.

Although this thesis seems controversial and perhaps not suited to a certain "political correctness", the view that most people's taste is bad is easy to prove. It is enough to figure out what books are most often bought, or tickets for what films in the cinema, or what kind of music is played in radio stations - in the democratic system, in the reality of the free market. So they will be: books that are easy to read; similarly, easy to watch movies that usually do not touch any important topics, which contain the appropriate dose of violence and sex, and very often also expensive CGI effects, and always end with a happy ending, contrary to many stories in real life.

These kinds of films are not usually produced as "works of the artistic mind" but as something that enables the viewer to turn off real life for a short period of time by "transition" to an easy, simple, uncomplicated, stimulating, pleasant, relaxing "non-reality" of the movies. It can also be added that a similar function is played by many computer and video games, especially by MMO games, though not only. The difference is that "entering" the created world of games usually takes longer and can have much more serious consequences, including choosing "imaginary reality" instead of the real world.

In the case of Masscult, therefore, we have assumed not only a certain simplicity of the product offered, or the attractiveness of certain artificial experiences, but also some escapism. Of course, I do not mean that a valuable film has to end in someone's tragedy, but there is no doubt that the standard 
Hollywood product must contain the above-mentioned elements. If it does not contain them, cinema tickets will not sell well, the producers will not be financially successful and the director will never be employed by the huge studio, because in mass culture everything is ruled by the money. Products offered by Masscult may be of the worst quality, so that only they sell well. The taste of most buyers (understanding their taste and adapting to it) is therefore a key issue for "pop culture managers"18. As Macdonald wrote, only a certain trained, thinking and most educated elite knows what is valuable in culture and is also seeking it; the rest are simply looking for the usual "fillers", i.e. for the most simple, enjoyable products of Masscult, which do not leave a reader or a viewer with any doubts, do not put inconvenient questions and nor require any cultural subtlety. This is also how Macdonald was remembered (like Ortega y Gasset and others), that is as a supporter of cultural elitism; cultural, but not political or economical ${ }^{19}$.

Examples showing the aptness of Macdonald's views, regarding that Masscult's development leads to a crisis of culture, could of course be multiplied; take, for example, the development of pop music. Initially, the radio was dominated by classical music and additionally music, which we would describe as popular, but which represented a certain level (e.g. cabaret and similar songs), then rock, today pop. The "artist" of pop music does not have to be able to compose or write lyrics, or even sing nicely. Instead, there must be a "product" that sells well, and that means something attractive. Thus, paradoxically, Masscult has led to the fact that the best singers are attractive people, not those who can or cannot sing. In other words, a modern pop artist should not only be able sing, but also must have a sexy look; and the latter is much more important, it seems. I am far from stating that rock music was a high culture ${ }^{20}$, but compared to what has

${ }^{18}$ Macdonald uses such terms as "technicians of Masscult" and "Lords of Masscult"; cf. Macdonald, Masscult \& Midcult, op. cit., pp. 9-10. According to him, Masscult managers generally have to listen to the masses' expectations, which obviously poses a threat to the level of culture in general; an example of such a scheme may be "a movie magnate who cynically gives the public what it wants i.e., assumes that it wants thrash"; cf. ibidem, p. 10. In another passage, we read that " [...] plebs have their dialectical revenge: indifference to their human quality means prostrations before her quantity"; cf. ibidem, pp. 9-10.

${ }^{19}$ Cf. James Seaton, Cultural Conservatism, Political Liberalism: From Criticism to Cultural Studies, University of Michigan Press, Ann Arbor 1996, p. 56.

${ }^{20}$ For Macdonald's views on the development of popular music in the United States cf., for instance, James L. Baughman, The Republic of Mass Culture: Journalism, Filmmaking, and Broadcasting in America Since 1941, JHU Press, Baltimore 2006, p. 73. 
been just mentioned, at least it was an authentic creative act and with authentic performance, and it is a certain value. Macdonald is right to mention the homogenization of the "mass culture" products". It is hard not to notice that in our time radio stations usually play "musical mush" (it can also be called "musical chewing gum"), i.e. songs that are almost no different from each other. And it is irrelevant who sings, what he sings about, whether he composed or wrote it himself, or not, and whether he can really sing; the only thing that matters is whether the Masscult participant, that is "a cog in a machine" already mentioned above, recognizes such a product as something that suits him, and whether he wants to buy it.

The same applies, of course, to the publishing market. It is known that the publishing house wants to earn; but if this becomes the ultimate goal, how does this affect the publishing market? Well, "the client pays and requires", this rule is binding in absolute terms. It is worth noting that today the ordinary author of an excellent volume of poems or a valuable novel, for example, has no chance of confronting a book (an autobiography, for example) written by celebrities, that is certain characters that are medially recognizable, though not necessarily active in the field of culture, as evidenced by the example of the Kardashian sisters and many other figures, who are "famous because of being famous"22. Such books will not sell because they are good books, but because the author, if it really is the author, occupies a particular position in the hierarchy of Masscult. And such a book will take the place of something valuable, a good novel for instance, that is a place of real cultural works addressing important topics, using beautiful, sophisticated language, which should be a standard both for literature and the publishing market. Thus, the publishing market begins to remind us of the jungles in which, as in Darwin's joyful dream, only the strongest, i.e. the best-adapted, can survive. Those "best", let us add, are the best not because they are originators in the field of culture, but because they are, at least sometimes, the most aggressive, ruthless, insolent, down-to-earth, deprived of morality and driven by the lowest motives (it is worth doing something horrible, if only they would talk about us). In the world of Masscult, a beginner, talented poet or writer for instance, has no

${ }^{21}$ Cf. Macdonald, Masscult \& Midcult, op. cit., p. 11.

${ }^{22}$ Cf., for instance, M. Kavka, Celevision: Mobilization of the Television Screen, [in:] A Companion to Celebrity, P. D. Marshall, S. Redmond (eds.), John Wiley \& Sons, Chichester 2015, p. 304. 
chance of survival; unless he starts playing the Masscult game, i.e. he wants to adapt, and that means realizing what is currently bestselling and concentrating on it. It is also advisable to massively promote oneself (a person, not a work).

It can be concluded that Masscult somehow lowers not only the quality of culture, but also "human quality", i.e. it creates a certain system of production and distribution of cultural goods, which assumes that a person should not have other needs and aspirations, apart from spending money and getting simple satisfaction in connection with the fast, one-time "consummation" of the Masscult product.

Intellectual or spiritual development caused by contact with a work of art, raising the level of culture among people, aesthetic experience etc., do not have the raison d'etre in this excessively commercialized reality; they are a kind of "cultural relic". In this reality, therefore, there is no significant difference between spending a certain amount of money, for example in a big shopping center, for a cinema ticket, a book or shoes. This and that are only products that have a price. In times before the dominance of mass culture, such a comparison - the purchase of shoes and the purchase of a ticket to a cinema, opera or theater - would be inappropriate; at present, it is only about the price and whether or not the customer decides to buy it. From a certain perspective, we can determine the dominance of Masscult as the ultimate victory of capitalism, though not only it (perhaps simply rather highly industrialized, modern society) ${ }^{23}$, over art and culture and, in a way, over $\operatorname{man}^{24}$. More or less the same can be said about

${ }^{23}$ It should be noted that according to Macdonald, Masscult is not just a matter of capitalism; he also writes about mass culture in the USSR; cf., for instance, Macdonald, Masscult \& Midcult, op. cit., p. 1-14. On McDonald's political beliefs cf., for instance, Richard H. Pells, The Liberal Mind in a Conservative Age: American Intellectuals in the 1940s and 1950s, Wesleyan University Press, Middletown 1989, p. 176.

${ }^{24}$ Regarding the reduction of "humane quality" in the age of mass culture, the cult of celebrities and the ubiquitous cultural exhibitionism of Masscult participants can be also mentioned, digressively. In a sense, a man, his feelings, his experiences etc., become a commodity, something that can be bought. The Kardashian family is just one such example. Family life, events from individual and family life become a new product of the era of mass media. In principle, there is no difference between a company producing something specific and a kind of media exhibitionism of the Kardashians or all other people who make a product of themselves: they are advertised, have better and worse sales periods etc. Of course, a lot of people, attitudes or ways of attracting mass attention and making money thanks to that can be included in this category. In mass culture, as one can see, the majority and money are always right. 
television productions, press and so on, namely that they are aimed at a mass audience and at the same time a mass buyer, and that the goal here is profit in the financial sense. Therefore, I think that Macdonald's description of the influence of Masscult on the development of culture has not become outdated: culture is totally commercialized, and quality does not count, but quantity (number of tickets sold, number of products sold, etc.). In other words, market laws have replaced previously-binding laws of cultural development; and since culture has been reduced to the market, "cultural activity" and "business activity" are currently synonymous with Masscult. The lowering of standards is assumed and desirable, which from the point of view of doing business (by a publishing house, a radio or television station, and so on) is understandable, because the point is to make the mass audience as "massive" as possible. In other words, with too good (in the old sense of the word, i.e. with too high quality) product, one will not achieve the expected financial success; such a product is by definition addressed to the elite. And now we are at this stage that there is no shame, no restrictions. The most outstanding perhaps exemplification of this is the "box office", i.e. the profit gained through the distribution of films is juxtaposed; the greater the profit in a shorter time, the better the movie is (and not because it is a valuable work, it may be so by the way).

According to Macdonald, the development of mass culture has led to a completely new situation. Previously, there was a clear division into high culture and folk culture, which was something qualitatively worse, but still a culture (Macdonald uses a certain pictorial description, comparing high culture to the garden of aristocrats living in the palace, nevertheless on the other side of the fence surrounding their garden there is a kitchen garden of simple people, not belonging to the upper class, who equally also have their own culture). On the other hand mass culture is, according to Macdonald, a kind of development of folk culture, but a deformed one. This is because folk culture functioned thanks to authentic cultural originators and, moreover, it assumed a certain participation of people, whereas in mass culture the place of cultural originators is taken by managers, and it is only about profit resulting from the sale. Lament over how folk art was being destroyed by modern, industrial civilization was not only expressed by Macdonald, but also by others, especially by some Frankfurt School's researchers, Clement Greenberg and James Agee, as James Naremore and Patrick Brantlinger 
notice ${ }^{25}$. At present, both the situation of high culture and authentic folk culture is difficult because they have to compete with mass culture; and this system is so perfectly designed and managed $2 \mathrm{q}$

QAgdsz that they do not have much chance of winning (as Macdonald wrote, "Lords of kitsch, in short, exploit the cultural need of the masses in order to make a profit and/or to maintain their class rule" ${ }^{26}$ ). They are in a losing position, because the market requires that the standards are not too high and that sales should always be at the highest level.

According to Macdonald, one of Masscult's strongest "weapons" in the fight against culture is the massiveness of the product offered; and neither high culture nor folk culture can be worthy of rivals here. It is difficult to disagree with this view. More specifically, we deal with: (a) the mass participant of culture; (b) the mass production; (c) the mass product that is offered (which is described by Macdonald as "homogenized").

An important role is played here by standardization of a product; however, it is assumed that the people and their needs will be also standardized, and so is indeed. The most prominent example of combining these three levels - where mass and standardization are the key - is probably the Hollywood. Here people actually expect a standardized product, and this means it has to be a happy end, movie stars (a movie that does not have such a star has a much lower chance of success, and of course actors and actresses should be attractive, because no one will go to a movie that does not have attractive, young-looking people to look at), car blasts, shootings, and of course there should a bit of sex or at least romance. Obtaining a standardized product is possible due to proper control over the production process; the director, the actors, the camera operator and other people are not allowed too much artistic freedom. For example, the movie director is not always allowed to edit the scenes of "his movie"; sometimes, though not often, the director's version can be shown. All this means that in such a case we are not dealing with authentic creativity in the field of film art. Of course, a director, just like a writer or artist, who is aware of the market requirements and how Masscult works and wants to submit to it, does not have to be supervised. But this means

${ }^{25}$ Cf. J. Naremore, P. Brantlinger, Introduction: Six Artistic Cultures, [w:] James Naremore, Modernity and Mass Culture, Indiana University Press, Bloomington 1991, p. 11.

${ }^{26}$ These are of course Macdonald's words, but Clement Greenberg also made similar criticism; cf. T. H. Schaub, American Fiction in the Cold War, University of Wisconsin Press, Madison 1991, p. 18. 
that he is becoming, at the same time, an originator in cultural field and a sort of censor ho censors himself. We can say that this is, in a sense, an absolute triumph of capitalism (or, in any case, highly industrialized contemporary society and economic system) over art ${ }^{27}$. Only that has the raison d'être what comes out of a certain social order, and which unites and consolidates such an order, allowing it to develop further. Probably every economic and political system has its own propaganda tools (in the broadest possible sense of the term; e.g. socialism will have its socialist art, and developed capitalism will have its capitalist Masscult). The question arises whether such a system leads to a crisis of values.

\section{Anti-culture and consumer society. The problem of the values}

To answer the question of whether mass culture causes a threat to values, one must first determine what the values are. According to the view of a neo-Kantian philosopher, Heinrich Rickert, values - as it has been mention above ${ }^{28}$ - are something that does not exist, but applies. So values are not beings in the traditional sense of the word; they are rather a kind of "signposts" that people choose in relation to their actions. Of course, from an academic point of view, the most important are the manifestation of values within the lives of certain human communities, or to put it somewhat differently, the validity of certain values (certain value systems) in culture, or in cultures.

According to Macdonald, the development and then the dominance of mass culture prevents the emergence of values and poses a threat to them. It should be emphasized that the American author does not express that directly, however it is undoubtedly his position. According to him, the very existence and dominating role of Masscult poses a threat to the following values:

a) work of art;

b) natural (or in other words, good, proper) human life;

c) natural (good, proper) life of the community.

Referring to art, to the work of an artist - which is a great value for Macdonald himself - he writes: "It [that is Masscult - T.S.] thus destroys all values,

${ }^{27}$ Macdonald was very critical of American capitalism; cf., for instance, Neil Jumonville, Critical Crossings: The New York Intellectuals in Postwar America, University of California Press, Berkeley 1991, p. 36.

${ }^{28}$ Cf., for instance, Martin, op. cit., pp. 126-135. 
since value judgments imply discrimination" ${ }^{29}$. So mass culture being totally democratic is sort of threat; since every taste is good, there is no reason to say that a work of art is better than kitsch. What is more, kitsch will be better if it sells better. According to Macdonald, we will deal with real cultural creativity not when we strive to increase our profits, but when artists manage to achieve a certain unity or cohesion through which they can express some important thoughts, ideas or feelings; and this cannot be achieved by a well-organized production line.

As for the value of human life in its natural form, Macdonald states, analyzing mass culture, that there might be a perversion of human life. Man ceases to be what he once was; as Macdonald writes: "The masses are not people, they are not The Man in the Street or the Average Man, they are not even [...] the Common Man. The masses are, rather, man as non-men"30. Such a "mass man"31 is a certain theoretical construct, but also an imaginary figure who "has no private life, no personal desires, hobbies, aspirations, or aversions that are not shared by everybody else"32. This means that "Mass man" is as unoriginal and devoid of content as possible; in other words, homogenization, mentioned by Macdonald, includes not only culture, but also the essence of man or perhaps humanity ${ }^{33}$. For example, adults begin to behave like children, and children like adults; he writes about adultized children and infantile adults ${ }^{34}$. In this way, certain "pre-existing order" is disturbed ${ }^{35}$, and even a certain degeneration occurs in the area of morality ${ }^{36}$; and in Macdonald's opinion, of course, it is mass culture to blame. A similar remark may be given, in the present times, in relation to, for example,

${ }^{29}$ Macdonald, Masscult and Midcult, op. cit., p. 11.

${ }^{30}$ Ibidem, p. 10

${ }^{31}$ Term "mass man" - cf., for instance, ibidem, p. 8.

${ }^{32}$ Ibiden, p. 10

${ }^{33}$ It is more than just culture. Referring to Masscult as a system of enslaving people, Macdonald writes, for example "The totalitarian regimes [...] have consciously tried to create the mass man"; cf. ibidem, p. 8.

${ }^{34}$ Cf. J. Foreman, The Other Fifties: Interrogating Midcentury American Icons, University of Illinois Press, Chicago 1997, p. 271.

${ }^{35}$ In Massult, human life in its normal, uncorrupt form is at risk; as Macdonald writes, "The question of Masscult is part of the larger question of the masses. The tendency of modern industrial society, [...] in the USA or in the USSR, is to transform the individual into the mass man"; cf. Masscult and Midcult, op. cit., p. 8.

${ }^{36}$ On the crisis of morality in mass society: "Its morality sinks to the level of the most primitive members - a crowd will commit atrocities that very few of its members would commit as individuals"; cf. ibidem, p. 9. 
some consent to brutalization in culture, especially in the film; or in relation to over-sexualization of Mascult products, especially in film and popular music. So, Macdonald, just a few decades ago, rightly realized how Masscult will continue to grow. There are, of course, many examples of "degeneration" in mass culture. Adults actually become a bit children: they watch SF movies, play games, are fans of certain characters from pop culture etc. These attitudes are probably best illustrated by the TV series The Big Bang Theory, where university employees talented academic teachers and scientists - live as young people, i.e. with colleagues in rented rooms, instead of living with their spouses and children. All their free time is spent for playing certain schemes in pop culture, or simply to participate in pop culture; for example, they visit a store with comics (for them, it is something like visiting a temple or going to a church), watch "cult" movies such as StarWars or StarTrek again and again, etc. ${ }^{37}$

On the other hand, some adult roles are attributed to children. This is particularly evident in the area of sexuality, or perhaps over-sexuality in the lives of children and adolescents. A significant proportion of children and adolescents have not only contact with drugs, but also with pornography, and thus with certain reserved areas, previously only for adults. The most clear illustration of the phenomenon of adultizing of children, as well as of the objectification of children in advertising and the media, was perhaps the cover of January 2011 issue of Vogue Paris. The child model, Thylane Blondeau, then a ten-year-old girl, was styled there for a sexy object of desire, wearing heavy make-up as she posing seductively on leopard print bed covers ${ }^{38}$. Probably some time ago the editors of the magazine would be accused of promoting pedophilia; currently, however, in the age of the developed Masscult, accustoming us to such things, we usually look at it with indifference. In mass culture, what was once simple and innocent

\footnotetext{
${ }^{37}$ How much they are frivolous people, i.e. how far this infantilization is going, is especially well shown in that this part of the series, in which the characters discuss what will happen if the vampire bites the zombies; will there be a new vampire, or a new zombie? The discussion is conducted quite seriously by people with $\mathrm{PhDs}$, highly respected in connection with their scientific achievements. This shows well the social acceptance of being not serious, even if you are an adult.

${ }^{38} \mathrm{Cf}$., for instance, URL = http://www.dailymail.co.uk/femail/article-2588272/ControversialChild-Model-Thylane-Blondeau-Covers-Jalouse-Magazine.html [16.03.2018].
} 
(e.g. child's world) becomes more brutal and more sexualized ${ }^{39}$; and what was serious and responsible (the world of their parents) becomes infantile, insignificant, not to say stupid.

A similar form "degeneration" - or alienation, in the precise meaning of the term - and therefore the rejection of certain values, can be said in relation to the image of man and woman in mass culture. Women are assigned male roles, features and tasks (e.g. decisive action, being a leader or aggressiveness). Similarly, men are assigned features considered feminine (e.g. hesitation, uncertainty, lack of determination $)^{40}$. This applies not only to certain social roles, but also to the appearance itself. There are many examples, for instance in the press men-models posing on the covers of magazines in dresses (men's fashion sometimes makes the appearance of a man looking like a woman $)^{41}$. Therefore, it is necessary to confirm the validity of the observations made several decades ago by Macdonald. These observations and predictions relate mainly to the fact that mass culture enables, promotes and seeks to replace a certain natural model of life with alternative models, perhaps because what is strange and original arouses interest and sells better.

According to Macdonald, as it has already been pointed out, mass culture also destroys the value of the normal, proper, natural life of the community; and such a life is also conditional for the proper functioning of the individual. As he writes, "the individual in a community is both more closely integrated to the group than is the mass man and at the same time is freer to develop his own

${ }^{39}$ Also films and TV series for children (e.g. some of Nickleodeon's studio productions, though not only, contain a lot of violence, vulgarity or simply ugliness, especially if compared with similar productions from a few decades ago).

${ }^{40}$ You could give a lot of examples from Hollywood production, for example replacing Star Wars Luke Skywalker as the main character, by Rey, in the latest parts of the saga, or (to some extent) replacing Mad Max with the female character, Imperator Furiosa in the last Mad Max movie. Men who were once key figures and leaders now hesitate or are weak; thus, women "take over", as the creators of these films themselves sometimes mention. Cf., for instance, URL $=\mathrm{https} / /$ www.theguardian.com/ commentisfree/2015/may/27/sexists-are-scared-of-mad-max-because-it-is-a-call-to-dismantle-patriarchies [16.03.2018].

${ }^{41} \mathrm{Cf}$. for instance URL = https://www.vogue.com/fashion-shows/fall-2017-menswear/viviennewestwood [16.03.2018]; URL = https://www.vogue.com/fashion-shows/spring-2012-menswear/rickowens [16.03.2018]. 
special personality"42. Just as Masscult is not a culture, mass society is not a real society either. According to Macdonald, "A community [...] is a group of individuals link to each other by concrete interests. Something like a family each of whose members has his or her special place and function while at the same time sharing the group's economic aims (family budget), traditions (family history), sentiments (family quarrels, family jokes), and values (That's the way we do it in this family!)" 43 .

In Masscult, community life also takes an alienated form, because if (as Masscult's managers want) we are all just consumers, we do not have anything more except this kind of relationship. Mass culture denies the possibility of normal or natural community life; it means the lack of a common identity, historical narrative, interests, aspirations or a moral and aesthetic sense. In addition, the "mass society" is somewhat uncreative by nature ${ }^{44}$. We have just become a "lonely crowd", i.e. a group of people sharing time and space, but otherwise having nothing to do with each other ${ }^{45}$. Referring to this issue Macdonald writes, for instance, about the mass man as "a solitary atom, uniform with the millions of other atoms" ${ }^{\prime \prime 6}$. We meet mainly in the cinema or at the match - participating in some show, as spectators - but we certainly will not be honest with each other, exchange views, give each other advice etc. ${ }^{47}$ We have neither common memories nor common aspirations and plans for the future. Everyone is alone and as such is "consuming the world"; alone, though in a large group of loners who are like him. As Macdonald writes, "the masses are in historical time what a crowd is in space: a large quantity of people unable to express their human qualities because they are related to each other neither as individuals nor as members of a community" 48 . Such a society, or rather a "society", is possible due

${ }^{42}$ Macdonald, Masscult and Midcult, op. cit., p. 8; as one can see, Macdonald valued not only individuality in relation to a work of art, but also in relation to human life.

${ }^{43}$ Ibidem.

${ }^{44}$ According to Macdonald, "a mass society, like a crowd, is inchoate and uncreative"; cf. Masscult and Midcult, op. cit., p. 9.

${ }^{45}$ Macdonald emphasizes the strong relationship between the real (normal, healthy) society, the life of the individual in such a society, and artistic creativity (i.e. the culture in a narrow sense); as he writes, "the past cultures I admire [...] have mostly been produced by communities, and remarkably small ones at that"; ibidem.

${ }^{46}$ Ibidem, p. 8.

${ }^{47}$ Ibidem.

${ }^{48}$ Ibidem. 
to the fact that culture promotes some negative values and models, including above all: a pattern of an ideal, i.e. mass cultural product; a pattern of individual human life (with the reversal of a certain natural order of values); and finally, the pattern of social relations (also with such a reversal).

\section{"Avenues of escape",} or whether mass culture must win. Conclusions

When analyzing Macdonald's considerations regarding the development and functioning of mass culture, two basic questions must be answered. First, whether and to what extent his view of culture is up to date. And secondly, whether Macdonald is right, thinking that Masscult means a crisis of values.

It seems that Macdonald was generally right in describing both the beginnings of Masscult and its essential features. Besides, he rightly predicted that it would gain a dominant position in relation to what he would call culture. He was right, claiming that Masscult will focus solely on profit, not on the quality of the cultural goods offered; therefore, in relation to these issues, Macdonald's position, I think, still remains valid.

On the other hand, of course, he could not predict what was to come, especially the revolution in the field of information transfer. We live in an age of information and cultural goods are now (very often, perhaps even usually) certain information. If in the middle of the twentieth century, that is in Macdonald's times, the production of a film or the publication of a book was connected with entering into a relationship with a certain "producer", a film studio or a publishing house; nowadays one can release a movie or a book by himself, for example on the Internet ${ }^{49}$. This, of course, does not mean that all such publications are valuable; nevertheless, it is possible for the author to go beyond this scheme of the functioning of Masscult (if your "product" is to sell badly, then of course we will not even start selling it, therefore it cannot even enter the cultural realm). For example, a volume of poetry that would not be published in the "old system" at all can still find its readers after it is released on the Internet, and thanks to it, it will enrich culture to a certain extent. What is more, some singers first enjoy success outside the world of great music publishing companies, enjoying it on the

\footnotetext{
${ }^{49}$ The most obvious example of the former is YouTube. When it comes to publishing books, now publishing them in an electronic version is also very simple.
} 
Internet, or at least sometimes this is the case. This is related to the distribution system of digital cultural goods, which is sometimes done with the exchange of money, and sometimes not. With the emergence of new means of social communication and a decline in the prices of certain technologies (for instance, buying a digital camera is not currently associated with a very large expense), some of Macdonald views regarding details of the functioning of culture have become obsolete; above all, they do not include the new ways of distribution of cultural goods.

The conviction of the American author that Masscult has its means of communication and that they are radio, cinema, comics, detective novels, science fiction stories and television (that is, these media "work only for Masscult"), is also outdated. At present, this view is unsustainable. For example, with so many radio or TV stations, it is hard to say that all are exclusively for profit. Similar views, voiced by some critics of mass culture, perhaps had their justification in the midtwentieth century; now one can easily give examples of radio or television stations that were created only to promote what Macdonald would call a high culture, for instance classical music. The situation is similar with the current comic books, i.e. it cannot be said that it is only a "low culture". Some comic book authors should be undoubtedly called artists, the more that for some time we have been dealing with a graphic novel - a genre that has brought comic book creation to the heights $s^{50}$. The same is true of science fiction, both literature and film. Some SF novels or SF films are well thought out and contain some deep content, and cannot be simply called kitsch. As an example, one can give novels of many authors, such as Stanislaw Lem or Philip K. Dick, for whom SF provides only certain means of expression to discuss quite important issues related to human existence and the place of man in the universe ${ }^{51}$.

Also Macdonald's views on alternative activities towards Masscult seem a bit archaic. As he wrote, there are only two escape routes: avant-garde and academicism, although the latter only seemingly, because it is kitsch for the elites.

${ }^{50}$ Cf., for instance, The Cambridge Companion to the Graphic Novel, Stephen E. Tabachnick (ed.), Cambridge University Press, Cambridge 2017, pp. 26-57.

${ }^{51}$ For example, issues such as: man and technology; technological development and the possibilities of enslaving society through technology; the essence of humanity (in comparison, for example, with a machine or a robot), and others. Referring to these and similar issues, the authors of more ambitious SF books or directors of more ambitious SF films show that the purpose of their activities is not just to provide entertainment. 
For him, high culture of our times is identical with avant-gardism. It seems, however, that Macdonald noticed in capitalist economy some "crannies" in which an intellectual or an artist can survive ${ }^{52}$. Today, it seems, such a division into mass culture, academism and avant-gardism is not something current. What is more, avant-gardism can use, for example, kitsch as a means of expression (such kind of kitsch is called, after Susan Sontag, camp $)^{53}$.

Let us now turn to the next question, namely whether the development and dominance of mass culture mean a crisis of values. Is Macdonald right about this? According to him, as has already been mentioned, Masscult poses a threat to the following values: the value of a work of art; the value of a "natural" (or "normal") human life; the value of a "natural" (or "normal") social relations. One should, however, consider whether mass culture sometimes brings something good and valuable. For example, it can be seen that Masscult allows access to culture for the broad masses of people who would not have participated in culture without it - and certainly not in this way as the elite did, for example going to the theater, opera, art gallery or a concert of classical music ${ }^{54}$. And if this argument is correct, then it is not reasonable to be as radical as Macdonald was, that is to say: either high culture or Masscult, either art or kitsch. In addition, it is worth considering whether values can disappear from culture at all.

The answer to such a question depends on whether we adhere to a pluralistic position with regard to the existence of values. If so, replacing, for instance, art as a certain value (in "high culture") with profit, or financial success (in mass culture), may mean replacing one value with the other; but this does not mean the end or crisis of all values as such. These remarks lead to a conclusion that Macdonald, totally rejecting Masscult as a threat to values, could not take up, and did not take up, a pluralistic position. According to him, if high culture is in crisis

${ }^{52}$ Cf. Pells, op. cit., p. 177.

${ }^{53}$ Cf. S. Sontag, Notes on Camp, Straus and Giroux, New York 1966. Therefore, deliberate kitschness is consciously used by prominent artists in order to conduct certain dialogue with the mainstream culture, to challenge certain trends in art, or to show what popular culture really is. Some artists, therefore, intentionally create kitsch, or "kitsch", but that does not mean that they enter the Masscult (in fact one can even have doubts about whether or not kitsch can be created deliberately, thoughtfully). In other words, contrary to what Macdonald wrote, a work of art can be kitsch, or maybe rather: kitsch can be a work of art.

${ }^{54}$ Another thing is that, according to Macdonald, what is offered as a "mass culture product" is not part of culture at all. 
- that is, if no new, real works of art appear - it means also a crisis of values; and there is no alternative or any simple solution to such a situation. In this perspective, material gain and the popularization of the mass product of the "culture industry" does not mean, of course, the implementation of any values. The supporter of the pluralist position would find that some values - such as work of art, or functioning of high culture for instance - may be replaced by other values (financial profit, for instance). Opponents of this approach, i.e. Macdonald for instance, would state that the simple fact of earning money thanks to selling Masscult's "cultural products" by no means balances the fall of art and culture, traditionally understood.

Are there any ways to protect ourselves against the overwhelming influence of mass culture; or, as Macdonald would say, the battle is basically lost and there will be nothing left of high culture? It should be said, answering such a question, that Macdonald could not notice certain things, because he, living in times different than ours, was not able to do so. Namely, he did not take into account the possibility of such development of certain technologies enabling the transfer of information (and therefore of certain cultural goods) which could significantly redefine the situation. These new means of transferring information, above all the Internet, did not weaken the dominant role of mass culture, but enabled a certain alternative. One could give many examples and illustrations in support of this thesis: independent publishing of books or films by the authors, for instance, without any help form "cultural industry". It is now quite simple and allows the introduction of new content to culture, including high culture, which is done without the commercial mechanisms governing Masscult. This means that Masscult system will not be able to include all forms of culture, because the use of new technologies alone may mean an escape from "the Masscult game". It is true that, for instance, even a valuable volume of poetry published by the author as an e-book will lose in the commercial area with the autobiography of a celebrity, but new content will be introduced into the culture. On the other hand, however, Masscult is, it seems, designed to always win. It will always successfully seek to "master" either high culture or avant-garde; or, at the very least, to "master" as much of the cultural area as possible. Capitalism, for instance, can earn income from the avant-garde or high culture, if it is profitable. It is also worth to notice that, on the other hand, originators of high culture area often strongly want to play "the Masscult game". Many examples of this scheme can be given, for 
example, attractively or even provocatively dressed female instrumentalists, playing classical music on instruments such as a violin, harp or lute, and thus on instruments associated with the area of high culture ${ }^{55}$. If they did not look so attractive, they would not have so many views on YouTube, but one can see that it matters to them the most (if they only want music, their outfit and attractiveness would not matter so much). There are also many other examples, like rock music, or some subcultures, such as punk rock subculture, or hip-hop, or grunge (it is of course not only about music styles, but also about some alter-culture, or even an alter-lifestyle). Initially, these trends were very alter-cultural, i.e. they were outside, or even against the mainstream of culture. Then, after some time, they entered the mainstream, becoming Masscult's "products", becoming absorbed by it, but also devoid of their initial value, gaining only marketing value. Therefore, wondering whether Macdonald was right when he claimed that Masscult means a crisis of values, perhaps we should look at it less radically than him. Masscult's dominant position, with the new means of production and distribution of cultural goods, does not yet mark the end of culture as such, nor does it mark the end of values as such.

Progress, including the advancement of certain technologies, is something that cannot be clearly understood before certain changes occur; and the consequences of such changes in the field of the functioning of culture and society are usually even more difficult to predict. Macdonald, however, cannot be denied the fact that he described the historical origins of mass culture well. He also predicted its victory over what he himself called high culture. We are undoubtedly living, at least in the West, in the era of Masscult's total domination. It is a perfectly designed, very effective system of exchange of cultural goods and money; and it does not seem that there is going to be a change in developed capitalism and that something would be able to replace such a system perfectly. Although, of course, it may turn out that the predictions of sociologists and cultural researchers will not, once again, bend progress and change.

\footnotetext{
${ }^{55} \mathrm{Cf}$., for instance, URL = https://www.youtube.com/user/CamilleandKennerly [08.03.2019].
} 


\section{References}

Baughman J. L., The Republic of Mass Culture: Journalism, Filmmaking, and Broadcasting in America Since 1941, JHU Press, Baltimore 2006.

Foreman J., The Other Fifties: Interrogating Midcentury American Icons, University of Illinois Press, Chicago 1997.

Hinds H. E., Motz M. F., Nelson A. M. S. (eds.), Popular Culture Theory and Methodology: A Basic Introduction, Popular Press, Madison 2006.

Jumonville N., Critical Crossings: The New York Intellectuals in Postwar America, University of California Press, Berkeley 1991.

Kammen M., American Culture, American Tastes: Social Change and the 20th Century, Knopf Doubleday Publishing Group, New York 2000.

Macdonald D., Masscult \& Midcult, [in:] H. E. Hinds, M. F. Motz, A. M. S. Nelson (eds.), Popular Culture Theory and Methodology: A Basic Introduction, The University of Wisconsin Press, Madison 2004.

Macdonald D., The Responsibility of Peoples and Other Esseys in Political Criticism, Greenwood Press, Westport 1976;

Marshall P. D., Redmond S. (eds.), A Companion to Celebrity, John Wiley \& Sons, Chichester 2015;

Naremore J., Modernity and Mass Culture, Indiana University Press, Bloomington 1991.

Peters J. D., Simonson P. (eds.), Mass Communication and American Social Thought: Key Texts, 1919-1968, Rowman \& Littlefield Publishers, Lanham 2004.

Schatz T., Hollywood: Cultural dimensions: ideology, identity and cultural industry studies, Taylor \& Francis, London 2004.

Schaub T. H., American Fiction in the Cold War, University of Wisconsin Press, Madison 1991.

Seaton J., Cultural Conservatism, Political Liberalism: From Criticism to Cultural Studies, University of Michigan Press, Ann Harbor 1996.

Sontag S., Notes on Camp, Straus and Giroux, New York 1966.

Tabachnick S. E. (ed.), The Cambridge Companion to the Graphic Novel, Cambridge University Press, Cambridge 2017.

Wilensky H. L., Mass Society and Mass Culture: Interdependence or Independence?, [in:] “American Sociological Review”, Vol. 29, No. 2 (Apr., 1964), pp. 173-197.

Wreszin M. (ed.), Interviews with Dwight Macdonald, Univ. Press of Mississippi, Jackson 2003. 


\title{
Streszczenie
}

\section{Czy kultura masowa oznacza kryzys wartości? Stanowisko Dwighta Macdonalda i kwestia jego aktualności}

\begin{abstract}
Dwight Macdonald wnikliwie opisał początki kultury masowej, lub Masscultu, i jej zasadnicze cechy. Poza tym słusznie przewidział, że Masscult - koncentrując się na zysku, a nie na jakości oferowanych dóbr kultury - uzyska dominującą pozycję w stosunku do kultury wysokiej. Nie mógł jednak przewidzieć tego, co dopiero miało nadejść, zwłaszcza rewolucji w dziedzinie przekazywania informacji, a także pojawienia się nowych sposobów dystrybucji dóbr kultury. Według niego, Masscult oznacza kryzys wartości. Jest tak dlatego, że zyski finansowe w żaden sposób nie równoważą upadku tradycyjnie pojmowanych sztuki i kultury. Kultura masowa stanowi zagrożenie szczególnie dla takich wartości, jak wartość dzieła sztuki, wartość „naturalnego” życia ludzkiego i wartość „naturalnych” stosunków społecznych.
\end{abstract}

Słowa kluczowe: Dwight Macdonald, kultura, teoria kultury, kultura masowa, Masscult, krytyka kultury masowej

\author{
Zusammenfassung \\ Bedeutet die Massenkultur eine Wertekrise? \\ Dwight Macdonalds Stellung und Frage ihrer Aktualität
}

Dwight Macdonald hat eingehend Anfänge der Massenkultur - der Masscult und ihre wesentlichen Eigenschaften beschrieben. Er hat treffend vorhergesehen, dass Masscult eine dominierende Stellung im Verhältnis zu der Hochkultur gewinnt, indem sie sich auf den Gewinn, und nicht auf die Qualität der angebotenen Kulturgüter konzentriert. Er konnte jedoch nicht vorhersehen, was erst kommen sollte: die Revolution im Bereich der Informationsvermittlung und das Auftauchen von neuen Vertriebswegen von Kulturgütern. Masscult bedeutet nach ihm eine Wertekrise, weil finanzielle Gewinne keinesfalls den Verfall der traditionellen Kunst und Kultur aufwiegen. Die Massenkultur bedeutet eine Bedrohung besonders für solche Werte wie der Wert des Kunstwerkes, der Wert des „natürlichen“ Menschenlebens und der Wert der „natürlichen“ sozialen Beziehungen.

Schlüsselworte: Dwight Macdonald, Kultur, Theorie der Kultur, Masscult, Kritik der Massenkultur

Ins Deutsche übersetzt von Anna Pastuszka 
Informacje o autorze:

TOMASZ STEFANIUK, doktor habilitowany, Instytut Filozofii, Uniwersytet Marii CurieSkłodowskiej w Lublinie; adres do korespondencji: Instytut Filozofii UMCS, Pl. Marii CurieSkłodowskiej 4, 20-031 Lublin; e-mail: tomasz.stefaniuk@poczta.umcs.lublin.pl 